\title{
The rarest of the rare: rediscovery and status of the critically endangered Belem Curassow, Crax fasciolata pinima (Pelzeln, 1870)
}

\author{
Eduardo França Alteff'; Gustavo Gonsioroski²; Marcelo Barreiros ${ }^{3}$; Leonardo Gabriel Campos de Oliveira Torres ${ }^{4}$; André Restel Camilo ${ }^{5}$; \\ Hugo Borghezan Mozerle ${ }^{6}$; Antônio Emanuel Barreto Alves de Sousa ${ }^{7,14}$; César Augusto Bronzatto Medolago ${ }^{8}$; Carlos Martínez'; \\ Diego Mendes Lima ${ }^{7,15}$; Flávio Kulaif Ubaid ${ }^{10}$; Eloisa Neves Mendonça ${ }^{11}$; Barbara Mizumo Tomotani ${ }^{12,13}$ \& Luís Fábio Silveira ${ }^{12,16}$
}

1 Biodiversity Consultoria Ambiental. Ituiutaba, MG, Brazil. ORCID: http://orcid.org/0000-0002-2231-222X. E-mail: eduardofalteff@gmail.com

2 Eudocimus Consultoria Ambiental. São Luís, MA, Brasil. ORCID: http://orcid.org/0000-0002-5323-3794. E-mail: gustavogonsioroski@hotmail.com

3 Jacareí, SP, Brasil. ORCID: http://orcid.org/0000-0002-1381-8544. E-mail: marcelomope@hotmail.com

${ }^{4}$ Guira-Guira Soluções Ambientais e de Engenharia Ltda. Belo Horizonte, MG, Brasil. ORCID: http://orcid.org/0000-0003-4558-9376. E-mail: Igot900@gmail.com

${ }^{5}$ Ecologia e Ação (ECOA). Campo Grande, MS, Brasil. ORCID: http://orcid.org/0000-0002-7400-2987. E-mail: andrerestel@gmail.com

${ }^{6}$ Caipora (Cooperativa para a Conservação da Natureza). Florianópolis, SC, Brasil. ORCID: http://orcid.org/0000-0003-0308-5014. E-mail: hbmbio@yahoo.com.br

${ }^{7}$ Instituto Chico Mendes de Conservação da Biodiversidade (ICMBio), Centro Nacional de Pesquisa e Conservação de Aves Silvestres (CEMAVE). Cabedelo, PB, Brasil.

${ }^{8}$ Universidade Federal de São Carlos (UFSCAR), Centro de Ciências Biológicas e da Saúde (CCBS), Programa de Pós-Graduação em Ecologia e Recursos Naturais. São Carlos, SP, Brasil. ORCID: http://orcid.org/0000-0002-5546-9207. E-mail: cesarmedolago@yahoo.com.br

9 Universidade Federal do Maranhão (UFMA), Departamento de Biologia (DEBI0). São Luís, MA, Brasil. ORCID: http://orcid.org/0000-0002-3169-4581. E-mail: nyctic@yahoo.com

${ }^{10}$ Universidade Estadual do Maranhão (UEMA), Centro de Estudos Superiores de Caxias, Departamento de Química e Biologia, Laboratório de Ornitologia. Caxias, Maranhão, Brasil. ORCID: http://orcid.org/0000-0001-8604-1206. E-mail: flavioubaid@gmail.com

${ }^{11}$ Instituto Chico Mendes de Conservação da Biodiversidade (ICMBio). Açailândia, MA, Brasil. ORCID: http://orcid.org/0000-0003-2228-8255. E-mail: eloisa.mendonca@icmbio.gov.br

${ }^{12}$ Universidade de São Paulo (USP), Museu de Zoologia (MZUSP). São Paulo, SP, Brasil.

${ }^{13}$ Museum of New Zealand Te Papa Tongarewa. Wellington, New Zealand. ORCID: http://orcid.org/0000-0002-8855-4803. E-mail: babi.mt@gmail.com

${ }^{14}$ ORCID: http://orcid.org/0000-0002-8339-8274. E-mail: antonio.sousa@icmbio.gov.br

${ }^{15}$ ORCID: http://orcid.org/0000-0002-3790-6928.E-mail: diego.lima@icmbio.gov.br

${ }^{16}$ ORCID: http://orcid.org/0000-0003-2576-7657. E-mail:Ifs@usp.br

\begin{abstract}
The Belem Curassow (Crax fasciolata pinima) is one of the most endangered birds in South America, without sightings of birds in the wild for 40 years. This subspecies is nationally and internationally classified as critically endangered and close to extinction, suffering from poaching and deforestation in its range. Here we present new records of free-living individuals made on three indigenous lands in Pará and Maranhão states: in part of Terra Indígena Mãe Maria, Bom Jesus do Tocantins, Pará; in locations within the Reserva Biológica do Gurupi/Terra Indígena Alto Turiaçu, Centro Novo do Maranhão, Maranhão; and around the Terra Indígena Rio Pindaré, Alto Alegre do Pindaré, Maranhão. We also provide recommendations to protect this bird via a dedicated conservation program which includes finding new individuals in non-sampled areas (north of BR-222), estimating population size, enhancing taxonomic and natural history knowledge, capturing wild animals in order to start urgent ex situ conservation programs, and developing environmental awareness programs with the local and indigenous populations.
\end{abstract}

Key-Words. Mutum-pinima; Indigenous lands; Reserva Biológica do Gurupi; Habitat loss; Poaching.

\section{INTRODUCTION}

The taxa currently subordinated to Bare-faced Curassow Crax fasciolata (C. f. fasciolata, C. f. pinima, C. f. grayi and the putative and mysterious C. f. xavieri) have allopatric distributions and are found from the south of Amazonas River to the west of Paraná state, also occurring in Bolivia, Paraguay and Argentina (del Hoyo et al., 2018a, b). While the male plumage is highly similar among the subspecies, females are easily distinguishable by the barred pattern of their back and tail, which 
varies from dark, almost black in C. f. pinima, to predominantly cream in C. f. grayi. Craxf. xavieri is only know from a color plate and a few photographs, without any specimen in scientific collections, hindering any detailed taxonomic study to assess its validity (Grantsau, 2010; del Hoyo et al., 2018a, b).

The Belem Curassow, Crax fasciolata pinima (Pelzeln, 1870 ) is endemic to Brazil and restricted to the Belem Centre of Endemism, originally inhabiting terra firme forests from the northwest of Maranhão east to northeast of Pará, east from the Tocantins River (del Hoyo et al., 2018a; BirdLife International, 2018a). This region is known for having the highest levels of habitat loss in all Amazon basin (Silva et al., 2005; del Hoyo et al., 2018a; BirdLife International, 2018a).

The Belem Curassow is one of the least known and most threatened birds in the planet and is in the very verge of the extinction: this subspecies is alarming rare, with an estimated population of less than 100 free-living birds, and none in captivity (Lees et al., 2013). Specimens of this curassow are rare in scientific collections and the last known sighting of a bird in the wild dates from 1978 (Novaes, 1978; Novaes \& Lima, 1998; Silveira, 2009; Portes et al., 2011). The lack of recent sightings, especially in areas frequently visited by ornithologists, combined with the high levels of poaching, deforestation and environmental change observed in the Belem Centre of Endemism, was decisive to rank this taxon as critically endangered in the Brazilian and global red lists (MMA, 2014; BirdLife International 2018b). Intensive field expeditions searching the species since 2004 in many localities in Pará state were unfruitful (see Portes et al., 2011). Nevertheless, after 40 years with no confirmed records, we present here the rediscovery of a few remaining individuals of $C$. f. pinima.

\section{MATERIAL AND METHODS}

Fieldwork took place in the Brazilian states of Pará and Maranhão. In Pará, we conducted field campaigns at the indigenous reserve Terra Indígena Mãe Maria (TIMM), located in the municipality of Bom Jesus do Tocantins $\left(05^{\circ} 08^{\prime} 48^{\prime \prime} \mathrm{S}, 48^{\circ} 52^{\prime} 09^{\prime \prime} \mathrm{W}\right)$. This 62.488 ha indigenous land is crossed by a railroad (Estrada de Ferro Carajás), a transmission line (Eletronorte S.A.) and the BR-222 highway (Brasil, 1986; Fernandes et al., 2008), and the study site was located in the south portion of the highway. TIMM mostly comprises primary forest (Almeida \& Vieira, 2010), with some patches of secondary forest in different stages of regeneration, especially nearby the areas used by the indigenous community.

In Maranhão, we concentrated the field campaigns in the north portion of the Reserva Biológica do Gurupi (Rebio do Gurupi), located in the municipality of Centro Novo do Maranhão $\left(03^{\circ} 15^{\prime} 57^{\prime \prime} S, 46^{\circ} 42^{\prime} 00^{\prime \prime} \mathrm{W}\right)$. The 271.000 ha nature reserve also includes the municipalities of Bom Jardim and São João do Carú (Lima et al., 2014). Field campaigns also took place in other two indigenous territories: the Terra Indígena Alto Turiaçu (TIAT) in
Centro Novo do Maranhão ( $\left.02^{\circ} 54^{\prime} 38^{\prime \prime} \mathrm{S}, 46^{\circ} 24^{\prime} 52^{\prime \prime} \mathrm{W}\right)$, and the Terra Indígena Caru (TIC) in Bom Jardim (03\%41'59"S, $\left.46^{\circ} 03^{\prime} 16^{\prime \prime} \mathrm{W}\right)$. TIAT spreads across 531.000 ha and TIC across 173.000 ha, both comprising a well-preserved terra firme forest. Together, they form one of the largest forest patches within Belem Centre of Endemism (De Luca et al., 2009; FUNAI 2018a; Fig. 1), which leads BirdLife International to classify this region as an Important Bird Area (IBA Gurupi; De Luca et al., 2009).

We searched for curassows in Pará from May 2004 to December 2018, totaling 336 hours of observations at TIMM. In Maranhão, we carried out field surveys between 07 and 17 November 2017 at the Rebio do Gurupi, TIAT and TIC, as well as nearby the municipality of Alto Alegre do Pindaré, totaling 90 hours of observations. We also set up camera traps in all localities and conducted interviews with the indigenous people who took part of our field studies.

\section{RESULTS AND DISCUSSION}

Our fieldwork resulted in a number of records of C. f. pinima in only four localities in Belem Endemism Centre (Fig. 1). In 09/11/2013, at 07:30 am a camera trap installed in a patch of primary forest $\left(05^{\circ} 14^{\prime} 35^{\prime \prime} S\right.$, $48^{\circ} 50^{\prime} 23^{\prime \prime}$ W, Fig. 2) recorded a male. In 16/10/2014, an indian observed another male on the surroundings of Mãe Maria River, on a road at the border of the forest $\left(05^{\circ} 14^{\prime} 40^{\prime \prime} S, 48^{\circ} 55^{\prime} 14^{\prime \prime} \mathrm{W}\right)$, both records in TIMM. Indigenous people reported that, in the past, they could see these birds in the riparian forests of the Mãe Maria and Jacundá rivers, but females were rarer. It has been reported that Crax f. pinima used to be found in beaches and river margins and, in 1977, individuals were still seen in forests along the Pindaré River, western Maranhão state (Sick, 1997), being more easily located when they access the riverine habitats for drinking. The indigenous people suggested that the species could be more abundant to the north of road BR-222 (still within TIMM but outside our study area) in comparison to the sampled area by us. Thus, in 08/07/2017, a visit was made to one of the indigenous villages located north of BR-222, where G.G. managed to take a picture of a male (Fig. 3) that was being raised by an indigenous family. They mentioned that were keeping a pair of birds, but we were no able to find the female in the surroundings. A fourth male was documented by camera trap in $11 / 07 / 2017$, at $09: 30 \mathrm{am}$ in a patch of submontane forest $\left(05^{\circ} 14^{\prime} 37^{\prime \prime} \mathrm{S}\right.$, $48^{\circ} 50^{\prime} 22^{\prime \prime} \mathrm{W}$ ) at TIMM.

In 11/11/2017, a pair of birds was observed in TIAT by D.L.M., C.A.B.M. and C.M. in a primary terra firme forest area close to a watercourse. They observed the birds at 06:25 am as soon as they heard the male alarm calls, which were recorded (Mendes, 2017). The birds quickly flew to the top of a tree, hiding between the leaves; another female could be seen further away, in the ground. In that same morning, the indians reported five other birds in different locations. TIAT and TIC are the regions with the best-preserved forests in Maranhão (Oliveira 
et al., 2011). Apart from these records, the indigenous people at TIC reported another male in captivity in Alto Alegre do Pindaré, Maranhão (Fig. 4). Finally, a single perched male was briefly observed and briefly filmed among branches and leaves on 06/12/2018 in a primary forest at Rebio Gurupi.

Previously to our study (1998-2009), this curassow have also been seen in the municipalities of Capitão Poço, Dom Eliseu, Paragominas, Santa Bárbara do Pará,
Tailândia and Tomé-Açu (see Portes et al., 2011). During these fieldwork we obtained only feeble verbal reports by interviewing local people, who stated that the subspecies would be found in very low densities in the forest reserves of the Grupo Agropalma, Tailândia municipality (Portes et al., 2011). Historical records from the literature reveal that Crax fasciolata pinima has been previously recorded in Pará in Cajutuba beach (Pelzeln, 1868-1870; Goeldi, 1896), around Belém (Goeldi \& Hagmann, 1902),

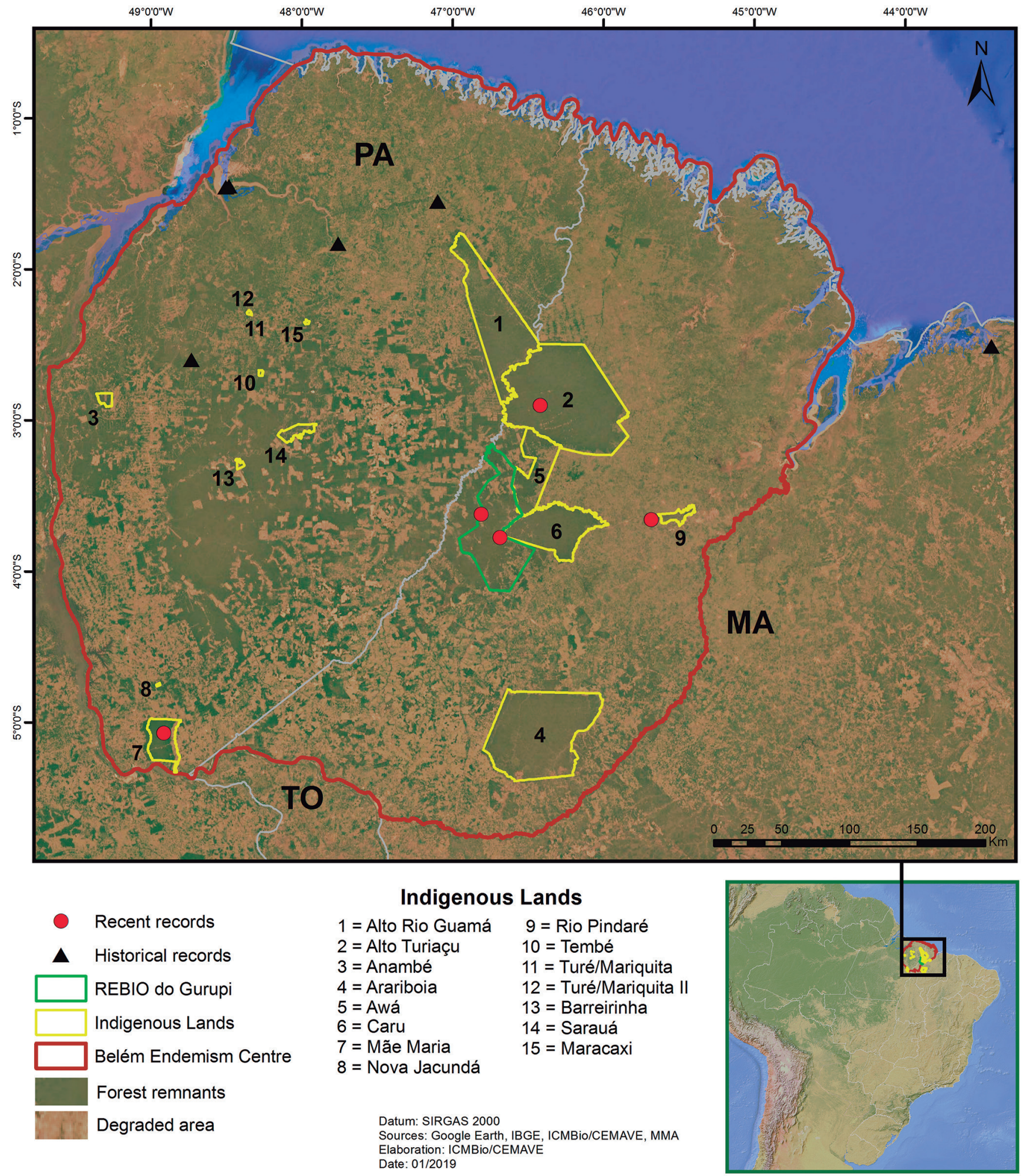

Figure 1. Study area, showing the historical and recent documented and undocumented records of Crax fasciolata pinima at the Belem Centre of Endemism. 


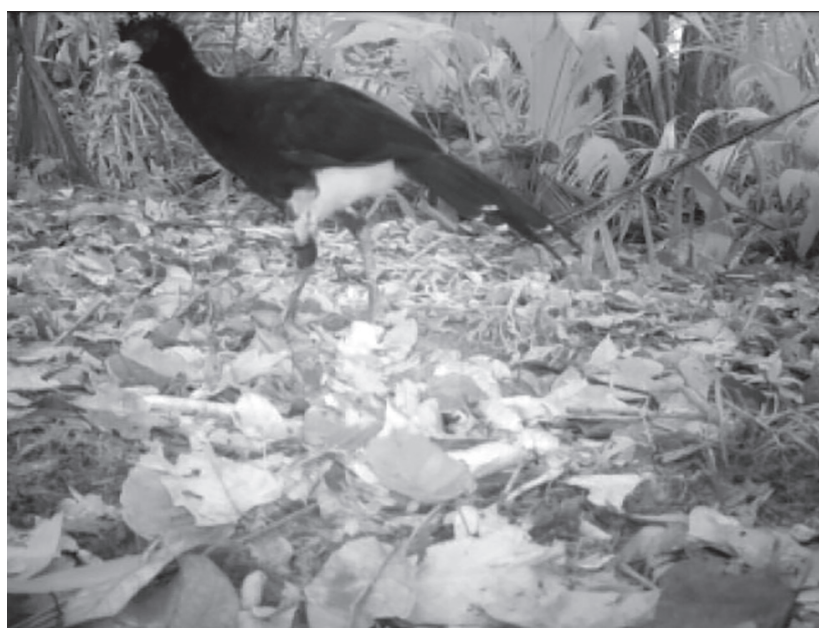

Figure 2. Crax fasciolata pinima male at the Terra Indígena Mãe Maria (TIMM). Images extracted from recordings of the camera trap.

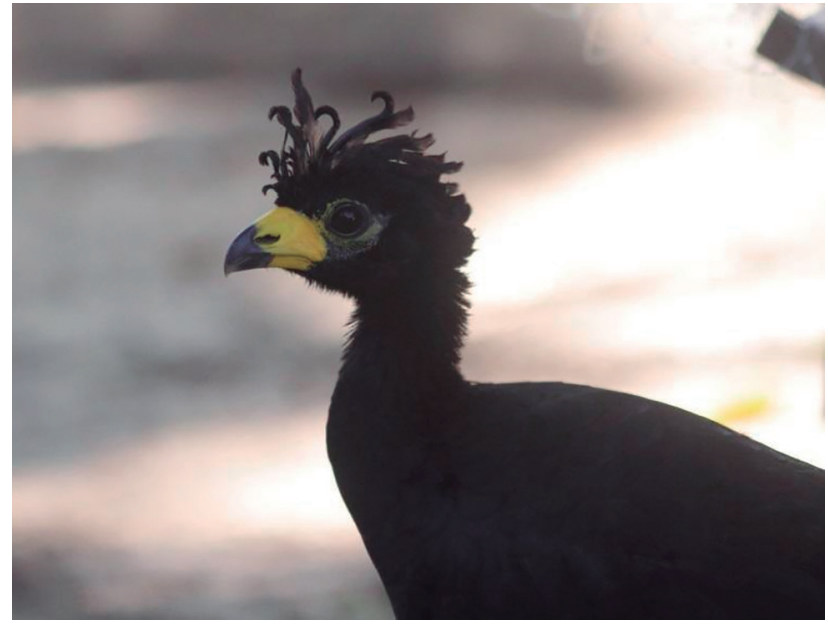

Figure 3. Crax fasciolata pinima male kept in captivity at the Terra Indígena Mãe Maria. Photo credits: Gustavo Gonsioroski.

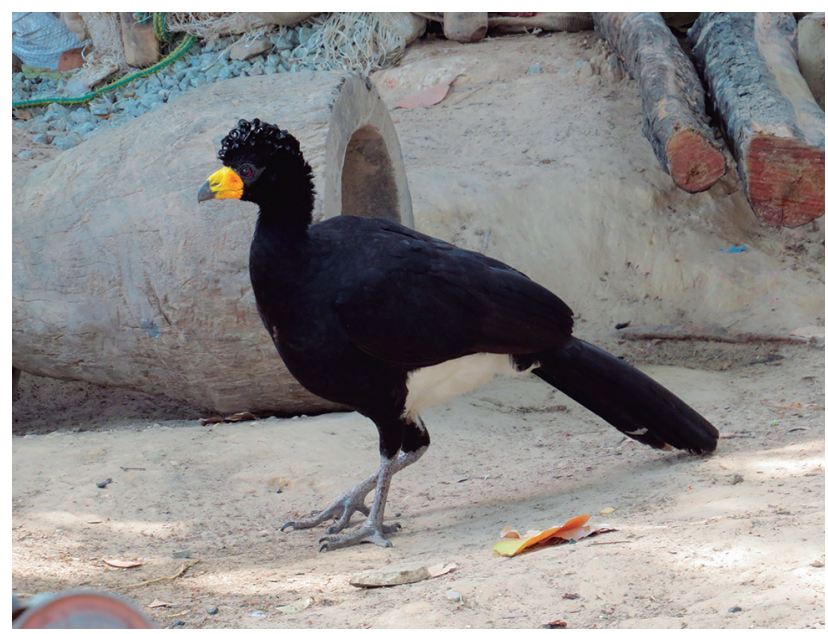

Figure 4. Crax fasciolata pinima male kept in captivity by a resident of the Marmorana settlement, Alto Alegre do Pindaré, Maranhão, Novembro 12 ${ }^{\text {th }}$, 2017. Photo credits: Emanuel Barreto.

Capim River (Goeldi, 1903; Snethlage 1914), Cametá (Hellmayr \& Conover, 1942; Vaurie, 1968), Marabá and Ourém (Novaes, 1978). In Maranhão, historical records include Santo Amaro do Maranhão, Primeira Cruz and

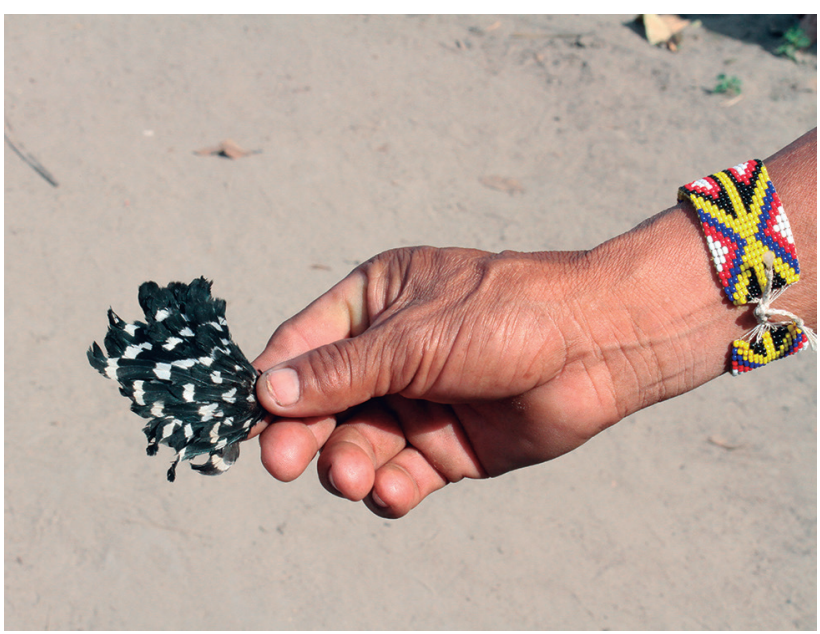

Figure 5. Female crest used by the indigenous ethnicity Ka'apor for the confection of ceremonial adornments. Photo credits: Diego Mendes

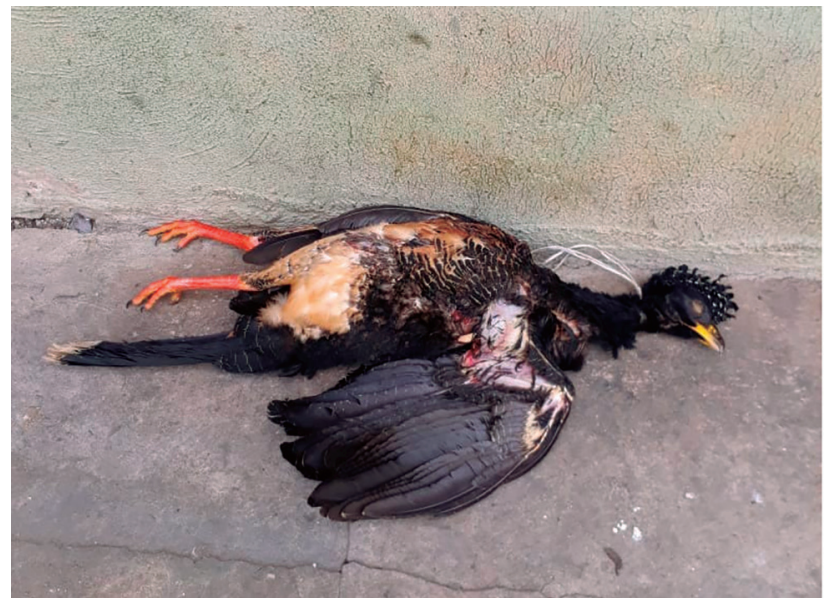

Figure 6. Recently poached female Crax fasciolata pinima in Maranhão.

Grajaú (Hellmayr \& Conover, 1942) and Pindaré rivers (Sick, 1979, 1997). Miguel Moreira, a collector, obtained the last known pair of C. f. pinima in February 1978 at lgarapé Pedral, a tributary of the right margin of Guamá River, Ourém, Pará (Fig. 1), which are deposited at Museu Paraense Emílio Goeldi.

Some authors have suggested that $C$. f. pinima might occur at the Rebio do Gurupi, in western Maranhão (Silveira, 2008; Portes et al., 2011; Lees et al., 2012), and our records support the presence of the bird in that conservation unit. Rebio do Gurupi still harbors the most pristine and typical areas of the Amazon Forest in Maranhão and connects to the indigenous territories Caru, Awá, Alto Turiaçú and Alto Rio Guamá (De Luca et al., 2009; FUNAI 2018a). The Ka'apor, an indigenous community resident at TIAT, mentioned that the "Mituxî" (name given to the Belem Curassow in Tupi language) inhabits isolated locations, far from the villages. The Ka'apor hunts the birds for food and use the female crown feathers as ceremonial ornaments (Fig. 5). Despite the lack of confirmed sightings, the residents of the TIC mentioned that the Belem Curassow could still be present on their land, in the headwaters of the Igarapé Presídio. Another area that still deserves further investigation is the indigenous land Terra Indígena Araribóia, a 413.000 ha of preserved 
forest area, located in the municipality of Amarante do Maranhão.

Amazonian indigenous reserves have been suffering illegal invasions, wood harvesting and poaching (Fernandes et al., 2008; FUNAI 2018b), leading to a reduction of natural areas and habitat quality, which is detrimental to the conservation of Crax f. pinima. These lands need a broader and more effective protection, with more thorough inspection, and creation of new fully protected conservation units. The Rebio do Gurupi is the most important reserve in the region and suffers from the development of the area into farmlands, illegal and unsustainable occupation, and high poaching pressure (Lima et al., 2014, Fig. 6).

The present study reveals the rarity of C. f. pinima, a species that still counts with free-living individuals, albeit in extremely low densities. Thus, the development of a specific conservation program for C. f. pinima in all indigenous lands of the region, and not only in the Rebio do Gurupi is of utmost importance, given that the taxon is, in all likelihood, on the brink of extinction. Further expeditions are necessary to search for more individuals and to estimate the reminiscent population size in a rigorous way, in order to a build solid basis for the proposal of a conservation program ex situ of the species. Moreover, species of the family Cracidae are known to be prolific birds in captivity, thus the capture of a few individuals for breeding in captivity can, in a relatively short time, considerably increase the population size, which should be managed through a Studbook program. Meanwhile, it is important to develop strategies in situ to allow a smooth reintroduction program as well as awareness programs together the local communities (indigenous and others) to minimize the hunting pressure on this species.

\section{ACKNOWLEDGEMENTS}

We thank the Programa de Áreas Protegidas da Amazônia (ARPA) for their financial support, Fundação Nacional do Índio (FUNAI) and the Instituto Chico Mendes de Conservação da Biodiversidade (ICMBio) for the permits for field work and institutional support during the expedition in Maranhão state. We are also grateful to Evane Alves Lisboa Chefe (Rebio do Gurupi) for supporting our research; to Francisco Walison Melo da Silva "Abelha" (ICMBio); to the indigenous chiefs from TIAT, namely Irakadju (Aldeia Turizinho), Pirahu (Aldeia Paracuí) and Karairano (Aldeia Xié); to the chief Pistola and all members from the Guardiões da Floresta (Terra Indígena Carú); and to Zezé Barros (Associação ka'apor ta hury do Rio Gurupi) for the support and dedicated work with the indigenous people. To the Brazilian National Council for Scientific and Technological Development (CNPq) for the grants to L.F.S. Marcello Brito (Grupo Agropalma), Roberto Azeredo and James Simpson (Crax Brasil), Pedro Nardelli, Bruho Ehlers (United Parcel Services, UPS) and Wilson Lemos de Moraes Neto (Fazenda Fartura) for the support.

\section{Author's contributions}

Eduardo França Alteff, Gustavo Gonsioroski, Marcelo Barreiros, Leonardo Gabriel Campos Torres, André Restel Camilo, Hugo Borghezan Mozerle, Antônio Emanuel Barreto Alves de Sousa, Cesar Augusto Bronzatto Medolago, Carlos Martinez, Diego Mendes Lima, Flávio Kulaif Ubaid, Eloisa Mendonça, Barbara Mizumo Tomotani \& Luís Fábio Silveira participated of the field work in Pará and Maranhão states. All authors contributed equally with data for the manuscript.

\section{REFERENCES}

Almeida, A.S. \& Vieira, I.C.G. 2010. Centro de endemismo Belém: status da vegetação remanescente e desafios para a conservação biológica e restauração ecológica. Revista de Estudos Universitários, Sorocaba, SP, 36: 95-111.

BirdLife International. 2018a. Species factsheet: Crax pinima. Available at: http://www.datazone.birdlife.org/species/factsheet/belem-curassowcrax-pinima. Accessed in: 22/06/2018.

BirdLife International. 2018b. Species factsheet: Crax fasciolata. Available at: http://www.datazone.birdlife.org/species/factsheet/bare-faced-curassowcrax-fasciolata. Accessed in: 14/07/2018.

Brasil. 1986. Decreto Federal № 93.148, de 20 de agosto de 1986. Homologa a demarcação administrativa da Terra Indígena Mãe Maria, no Estado do Pará. Diário Oficial da União, Seção 1, de 21 de agosto de 1986.

De Luca, A.C.; Develey, P.F.; Bencke, G.A. \& Goerck, J.M. (Eds.). 2009. Áreas importantes para a conservação das aves no Brasil. Parte II - Amazônia, Cerrado e Pantanal. São Paulo, SAVE Brasil.

del Hoyo, J.; Collar, N.; Christie, D.A. \& Sharpe, C.J. 2018a. Belem Curassow (Crax pinima). In: del Hoyo, J.; Elliott, A.; Sargatal, J.; Christie, D.A. \& de Juana, E. (Eds.). Handbook of the Birds of the World Alive. Barcelona, Lynx Edicions. Available at: http://www.hbw.com/node/467090. Accessed in: 28/02/2018.

del Hoyo, J.; Kirwan, G.M. \& Sharpe, C.J. 2018b. Bare-faced Curassow (Crax fasciolata). In: del Hoyo, J.; Elliott, A.; Sargatal, J.; Christie, D.A. \& de Juana, E. (Eds.). Handbook of the Birds of the World Alive. Barcelona, Lynx Edicions. Available at: http://www.hbw.com/node/53316. Accessed in: 28/02/2018.

Fernandes, R.F.; Cardoso, W.R.S. \& Sá, J.D.M. 2008. Os usos e proteção da floresta pelo povo Kyikatêjê: soberania e autodeterminação. In: Reunião Brasileira de Antropologia, 26a. Anais, Porto Seguro, Sociedade Brasileira de Antropologia. Available at: http://www.abant.org.br/conteudo/ ANAIS/CD Virtual 26 RBA/grupos de trabalho/trabalhos/GT\%2012/ rosani\%20de\%20fatima\%20fernandes.pdf. Accessed in: 30/06/2018.

Fundação Nacional do Índio (FUNAI). 2018a. Terras Indígenas do Brasil. Available at: http://www.funai.gov.br/index.php/servicos/ geoprocessamento. Accessed in: 28/06/2018.

Fundação Nacional do Índio (FUNAI). 2018b. 0 povo Awá-Guajá. Available at: http://www.funai.gov.br/index.php/ascom/1815-0-povo-awa-guaja. Accessed in: 29/06/2018.

Goeldi, E.A. 1896. Contornos para a avifauna do Pará e da Amazônia inferior, conforme o material dos três colecionadores mais importantes [Natterer, Wallace, Layard]. Boletim do Museu Paraense de História Natural e Ethnographia, 1(1-4): 336-356.

Goeldi, E.A. 1903. Ornithological results of an expedition up the Capim River, State of Pará, with critical remarks on the Cracidae of Lower Amazonia. Ibis, 45(4): 472-500. 
Goeldi, E.A. \& Hagmann, G. 1902. Lista das aves indicadas como provenientes da Amazônia nos 27 volumes do "Catalogue of Birds of British Museum" de Londres (1874-1898). Boletim do Museu Paraense de História Natural e Ethnographia, 3(1-4): 276-327.

Grantsau, R. 2010. Guia completo para Identificação das Aves do Brasil. São Carlos, Vento Verde. v. 1.

Hellmayr, C.E. \& Conover, B. 1942. Catalogue of birds of the Americas and the adjacent islands. Field Museum of Natural History, 13, pt. 1, (1): 1-636.

Lees, A.C.; Moura, N.G.; Dantas, S.M. \& Thompson, I. 2013. Capital Birding: Belém, Pará, Brazil. Neotropical Birding, 13: 32-42.

Lees, A.C.; Moura, N.G.; Silva, A.S.; Aleixo, A.L.P.; Barlow, J.; Berenguer, E.; Ferreira, J. \& Gardner, T.A. 2012. Paragominas: a quantitative baseline inventory of an Eastern Amazonian avifauna. Revista Brasileira de Ornitologia, 20(2): 93-118.

Lima, D.M.; Martínez, C. \& Raíces, D.S.L. 2014. An avifaunal inventory and conservation prospects for the Gurupi Biological Reserve, Maranhão, Brazil. Revista Brasileira de Ornitologia, 22(4): 317-340.

Mendes, D. 2017. XC395276, mutum-de-penacho, Crax fasciolata pinima. Available at: http://www.xeno-canto.org/395276.

Ministério do Meio Ambiente (MMA). 2014. Portaria № 444, de 17 de dezembro de 2014. Lista Nacional Oficial de Espécies da Fauna Ameaçadas de Extinção. Diário Oficial da União, Seção 1, número 245, de 18 de dezembro de 2014, p. 121-126.

Novaes, F.C. 1978. Sobre algumas aves pouco conhecidas da Amazônia brasileira Il. Boletim do Museu Paraense Emílio Goeldi, série Zoologia, (90): 1-15.

Novaes, F.C. \& Lima, M.F.C. 1998. Aves da Grande Belém: Municípios de Belém e Ananindeua. Belém, Editora do Museu Paraense Emílio Goeldi. 415p.
Oliveira, T.G.; Gerude, R.G.; Dias, P.A. \& Resende, L.B. 2011. Utilização de caça pelos índios Awá/Guajá e Ka'apor da Amazônia maranhense. In: Martins, M.B. \& Oliveira, T.G. (Eds.). Amazônia Maranhense: diversidade e conservação. Belém, MPEG. p. 270-279.

Pelzeln, A. von. 1868-1870. Zur Ornithologie Brasiliens. Resultate von Johann Natterers Reisen in den Jahren 1817 bis 1835, parts I-IV. Vienna: Pichler's Witwe \& Sohn.

Portes, C.E.B.; Carneiro, L.S.; Schunck, F.; Silva, M.S.S.; Zimmer, K.J.; Whittaker, A.; Poletto, F.; Silveira, L.F. \& Aleixo, A. 2011. Annotated checklist of birds recorded between 1998 and 2009 at nine areas in the Belém area of endemism, with notes on some range extensions and the conservation status of endangered species. Revista Brasileira de Ornitologia, 19(2): 167-184.

Sick, H. 1979. Notes on some Brazilian birds. Bulletin of British Ornithologists Club, 99(4): 115-120.

Sick, H. 1997. Ornitologia brasileira. Rio de Janeiro: Nova Fronteira.

Silva, J.M.C.; Rylands, A.B. \& Fonseca, G.A.B. 2005. 0 destino das áreas de endemismo da Amazônia. Megadiversidade, 1(1): 124-131.

Silveira, L.F. 2008. Crax fasciolata pinima. In: Machado, A.B.M.; Drummond, G.M. \& Paglia, A.P. (Eds.). Livro vermelho da fauna brasileira ameaçada de extinção, v. 2. Braślia: Ministério do Meio Ambiente.

Silveira, L.F. 2009. Encontrado o lendário mutum-pinima! Cães e Cia., 361: 6-7. Snethlage, E. 1914. Catálogo das aves amazônicas. Boletim do Museu Paraense de História Natural e Ethnographia, 8: 1-530.

Vaurie, C. 1968. Taxonomy of the Cracidae (Aves). Bulletin of the American Museum of Natural History, 138: 131-260. 